\title{
Computation of Various Irrigation Losses on Different Soils Using Remote Sensing, CROPWAT and GIS
}

\author{
Ch Ramesh Naidu ${ }^{1}$ and MVSS Giridhar ${ }^{2}$ \\ ${ }^{1}$ Civil Engineering Department, Gayatri Vidya Parishad College of Engineering(A), Visakhapatnam, Andhra \\ Pradesh, India \\ ${ }^{2}$ Centre for Water Resources, Jawaharlal Nehru Technological University, Hyderabad, Telangana State, India \\ Email: rameshnaidu@gvpce.ac.in
}

\begin{abstract}
To determine the irrigation requirements of rice crop in a canal command area on different soils, remote sensing images were used in conjunction with CROPWAT model and GIS technology. Satellite data were used to estimate the rice and fallow lands. Depending on the type of soil, climate and the crop acreage, the water requirement for rice fields is derived. In conjunction with satellite interpreted data, climate and soil data were also integrated in GIS platform. CROPWAT model was used to determine the crop evapotranspiration. There are 11 Water User's Associations in the command area under which 13 Canal blocks were delineated. These canal blocks were again delineated in to 212 sub blocks. In this study, the use of GIS and Remote Sensing with CROPWAT model to derive the crop water requirements at WUA and sub-block level showed distinct variation in water requirements due to the change in soil and climate parameters.
\end{abstract}

Keywords: Evapotranspiration, CROPWAT, GIS, remote sensing, canal command area and water user's association

\section{$1 \quad$ Introduction}

The estimation of water demand is an important component for managing the water effectively in the canal command area. Due to the urbanization and industrialization, water supplies for agricultural irrigation have become more difficult and costly. For effectively and efficiently using the available water sources to meet the demand, irrigation management plays an important role. One of the reasons for low efficiency is the un-accounted volume of water loss due to percolation in the rice fields and conveyance and seepage losses occurred during the water distribution through canals to fields. These losses are accounts in calculating Total water demand in addition to crop evapotranspiration. Besides this, a traditional way of calculating Irrigation Demand and the absence of scientific approach and adoption of new technologies is another reason. What should also be noted is the lack of working knowledge about proper water management due to lack of complete information about the command area including its water resources, distribution system details, land use, cropping patterns, soil, geology, climate and socio economic factors of the area. GIS technology in conjunction with Remote Sensing has proved to be effective for land use and water management. For effective management of water, stressing the need of generation of spatial and non-spatial database by integrating the Remote Sensing and GIS technologies with ground data is essential.

Multispectral and multi-temporal remote sensing data are very useful and with this, cartographic and data overlaying capability of GIS coupled with its dynamic linking ability plays a vital role in efficient water management. Resulting disparities exist in the availability of water between head-reach and tail end farms and between large and small farms, which reflects some portions of the command area posing water shortage and water logging problems due to under and over utilization of canal water. This demands the calculation and analysis of irrigation water requirements of the command area in detail up to water users association, block and minor canal level by using the latest available technologies for optimum utilization of irrigation water. 


\section{$2 \quad$ Adopted Procedure}

Since the dominant crop of the study area is rice, multi-spectral and multi-temporal satellite imagery on the basis of crop calendar for rabi season were procured from National Remote Sensing Centre(NRSC), Hyderabad, India. The satellite imageries of IRS P6 LISS III in the initial crop development stage and in the late mid season stage were selected for the present study. SOI toposheets at 1:25000 scale were collected and used to study topography and base features of the study area [1]. The SOI topomaps were also used to georeference the satellite images. Water User's Association (WUA) boundary maps were collected from the Water and Land Management Training and Research Institute (WALAMTARI), Hyderabad and integrated in GIS platform. Soil data, daily meteorological data, climate and rainfall data, crop and cropping pattern details were collected from the irrigation and agriculture department to study the evapotranspiration, percolation/seepage loss and conveyance losses of the command area. Daily meteorological data were collected from the nearest and most representative meteorological station.

The satellite imageries after being georeferenced with respect to SOI topo sheets were digitally enhanced to extract appropriate information [1,2 and 3]. The crop acreage for Wazirabad command area was estimated from the satellite imageries and this was based on the unsupervised classification using Erdas imagine software. The crop acreage reports were then generated WUA wise in GIS platform to find out the water requirements for each WUA.

CROPWAT model was used to carry out standard calculations for reference evapotranspiration and crop water requirements. CROPWAT model uses the FAO (1992) Penman-Montieth method for calculating the reference crop evapotranspiration [7 and 9]. Soil is taken as main parameter for calculating the percolation losses since the soils in command area are distributed with different soil categories. The irrigation in Wazirabad command area is distributed by unlined canals. Conveyance losses were calculated based on FAO's guidelines and US Bureau of Reclamation Data. Soil infiltration losses were calculated using overlay analysis with canal, soil and WUA themes in GIS [4, 5 and 6]. Net irrigation water requirements were computed by summing up losses of crop evapotranspiration, percolation and conveyance loss on daily and 10 day basis [8]. The procedure for calculation of irrigation water requirements was described in the flow chart (Fig.1).

\section{$3 \quad$ Results and Discussions}

Considering the importance of agricultural water use, the present study was aimed at providing detailed computations of irrigation water requirements for the Wazirabad canal command area, useful for inferring the temporal and spatial patterns of canal water withdrawals at WUA wise. To compute the WUA, canal and block wise water requirements, the canals and WUA boundaries were identified, delineated and digitized from the 1:25000 SOI topo maps. WUA maps and the digitized canal data are converted in GIS platform using Arc GIS network model (Fig.2). Using LISS-III satellite images for rice crop classification gives acceptable results. The CROPWAT model is very sensitive to climate and crop growth data. Hence, the input data of this model should have high accuracy. This model offers reasonable results for rice crop water requirements. The crop water requirements for WUA wise are calculated (Table.1). The supply to WUAs 20, 21, 23, 24 and 25 is less than the estimated value and for WUA 19, 22, 26, 27, 28 and 29 has delivered more water compared to estimated demand. The soils of the study area are initially classified in to 6 units and then reclassified and merged in to 3 classes viz. loam, clay and sand. In some WUAs, the crop evapotranspiration is $37 \%$ and field percolation losses are $61 \%$ out of the total irrigation demand. But in some WUAs the crop evapotranspiration loss is accounted $60 \%$ and percolation losses are 37\% (Table.2). This difference resulted due to the soil characteristics in those WUAs. 


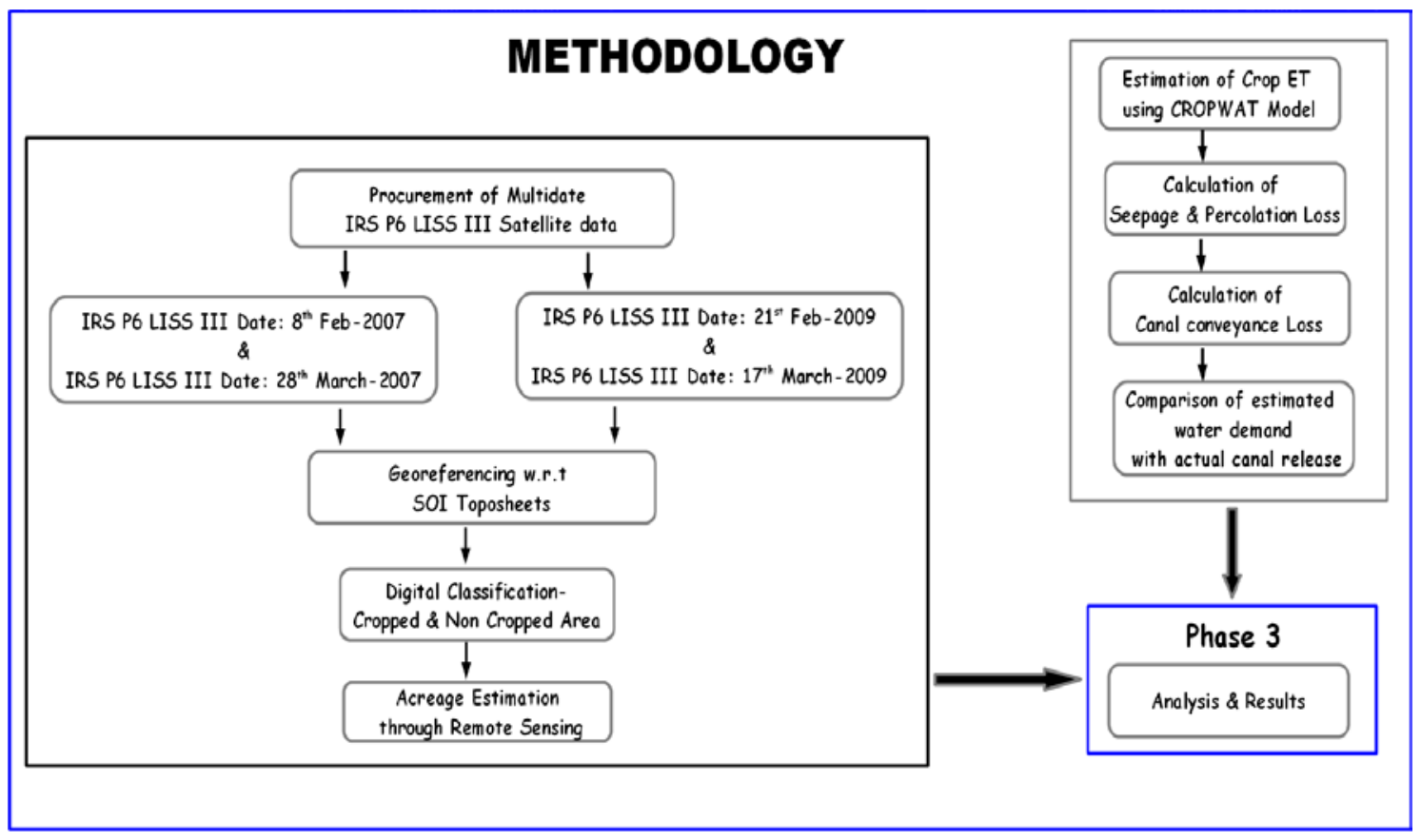

Figure 1. Methodology for the study

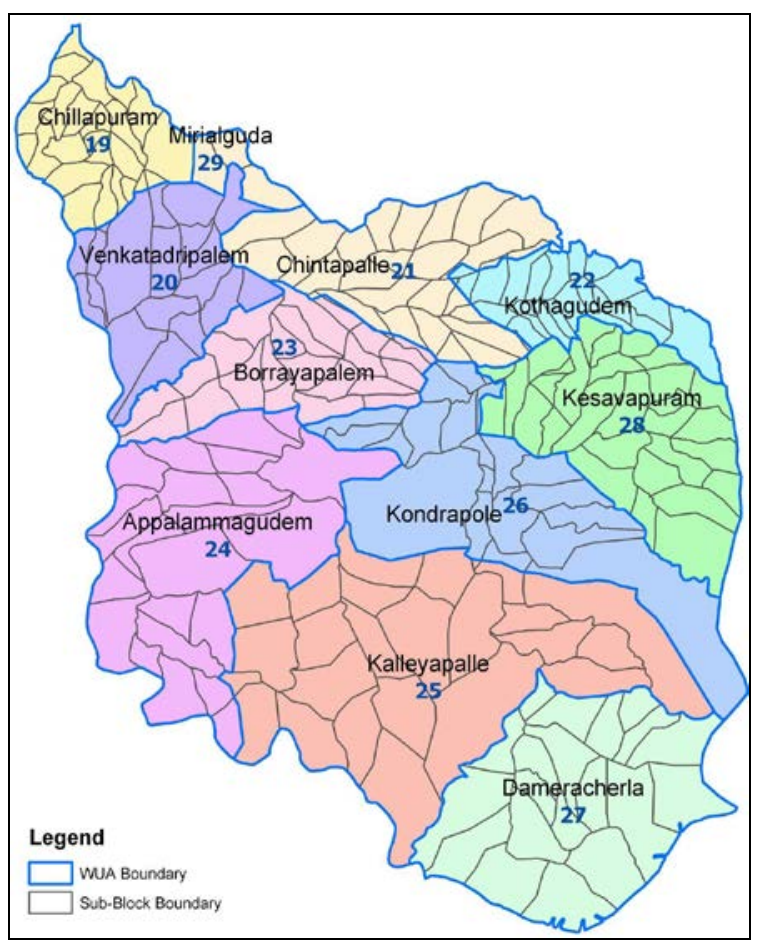

Figure 2. WUA and canal/ block \& sub-block boundaries in GIS environment. 
Table 2. WUA wise crop acreage and Irrigation demand.

\begin{tabular}{|c|c|c|c|c|c|c|c|}
\hline $\begin{array}{l}\text { WUA } \\
\text {-ID }\end{array}$ & WUA Name & $\begin{array}{l}\text { Gross } \\
\text { Command } \\
\text { Area } \\
\text { (hectares) }\end{array}$ & $\begin{array}{l}\text { Rice crop } \\
\text { (hectares) }\end{array}$ & $\begin{array}{l}\text { Crop } \\
\text { Evapotranspiration } \\
\text { losses (million } \\
\text { litres) } \\
\end{array}$ & $\begin{array}{l}\text { Percolation } \\
\text { Losses } \\
\text { (million } \\
\text { litres) } \\
\end{array}$ & $\begin{array}{l}\text { Conveyance } \\
\text { Losses } \\
\text { (million } \\
\text { litres) }\end{array}$ & $\begin{array}{l}\text { Irrigation } \\
\text { Water } \\
\text { Requirements } \\
\text { (million litres) } \\
\end{array}$ \\
\hline 19 & Chillapuram & 1340.67 & 1016.084 & 6498.9 & 10567.3 & 781.78 & 17847.92 \\
\hline 20 & Venkatadripalem & 1879.67 & 1409.688 & 9016.4 & 14660.8 & 635.23 & 24312.35 \\
\hline 21 & Chinthapalle & 2124.50 & 1916.24 & 12256 & 19928.9 & 887.83 & 33073.00 \\
\hline 22 & Kothagudem & 1180.00 & 954.901 & 6107.5 & 9930.97 & 462.09 & 16500.60 \\
\hline 23 & Borrayapalem & 1753.08 & 1697.508 & 10857 & 17355.4 & 882.84 & 29095.49 \\
\hline 24 & Appalammagudem & 3253.91 & 1884.585 & 12054 & 9197.77 & 1377.5 & 22629.12 \\
\hline 25 & Kalleyapalle & 6482.18 & 1376.56 & 8804.5 & 6467.04 & 969.84 & 16241.36 \\
\hline 26 & Kondrapole & 2740.18 & 1191.911 & 7623.5 & 8479.02 & 861.13 & 16963.61 \\
\hline 27 & Dameracherla & 3324.88 & 257.559 & 1647.3 & 730.166 & 826.17 & 3203.68 \\
\hline 28 & Kesavapuram & 2366.94 & 1423.473 & 9104.5 & 11822.6 & 1114.00 & 22041.14 \\
\hline 29 & Mirialguda & 279.42 & 193.583 & 1238.2 & 2013.26 & 142.36 & 3393.78 \\
\hline
\end{tabular}

Table 2. WUA wise losses in percentage on different soils

\begin{tabular}{lllllll}
\hline WUA & WUA Name & $\begin{array}{l}\text { Gross } \\
\text { command } \\
\text { area }\end{array}$ & $\begin{array}{l}\text { Evapotranspiration } \\
\text { in } \%\end{array}$ & $\begin{array}{l}\text { Percolation } \\
\text { loss in } \%\end{array}$ & $\begin{array}{l}\text { Conveyance } \\
\text { loss in } \%\end{array}$ & Soil Type \\
\hline 19 & Chillapuram & 1340.67 & 36.41 & 59.21 & 4.38 & Sand and Silt \\
20 & Venkatadripalem & 1879.67 & 37.09 & 60.30 & 2.61 & Sand and Silt \\
21 & Chinthapalle & 2124.50 & 37.06 & 60.26 & 2.68 & Sand and Silt \\
22 & Kothagudem & 1180.00 & 37.01 & 60.19 & 2.80 & Sand and Silt \\
23 & Borrayapalem & 1753.08 & 37.32 & 59.65 & 3.03 & Sand and Silt \\
24 & Appalammagudem & 3253.91 & 53.27 & 40.65 & 6.09 & Silt and Clay \\
25 & Kalleyapalle & 6482.18 & 54.21 & 39.82 & 5.97 & Silt and Clay \\
26 & Kondrapole & 2740.18 & 44.94 & 49.98 & 5.08 & Silt \\
27 & Dameracherla & 3324.88 & 51.42 & 22.79 & 25.79 & Clay \\
28 & Kesavapuram & 2366.94 & 41.31 & 53.64 & 5.05 & Silt \\
29 & Mirialguda & 279.42 & 36.48 & 59.32 & 4.19 & Sand and Silt \\
\hline
\end{tabular}

\section{Conclusions}

Geographic Information System (GIS) could be utilized as a best tool to derive and analyze the shortfalls of the system at WUA and canal level and suggest a solution at the time of peak demands and water shortfall. WUA and canal/block level GIS database allows irrigation managers to access information and results spatially in the form of maps, tables and graphs to support planning and decision making process. The percolation and conveyance losses were calculated in GIS environment. The increase of losses is primarily due to the increase of crop acreage. There is a remarkable difference in percolation losses between WUA to WUA due to the varied soil types in the command area. This difference has clearly resulted due to crop extent and the type of soil. The conveyance losses are comparatively much lower than the percolation and crop evapotranspiration losses. The conveyance losses are 8940 million litres. This study indicates that there exists a 5 to $20 \%$ of water deficiency in some WUAs and also water surplus in some WUAs varying from 15 to $40 \%$. Further, the analysis can be extended to study the detailed crop water requirements at micro level or farm level. 


\section{References}

1. Nitin Dubey R. K., Awasthi M. K. and Tiwari Y.K.2005). "Topographic analysis through Digital Elevation Model (DEM) for Patan Branch Canal command area using RS and GIS". Land and Water Management, Book 1, Conference paper, Command area development and management $4: 136-141$.

2. Rao P.P.N. and Mohan Kumar A. (1994). "Cropland inventory in the command area of Krishnarajasagr project using satellite data". International Journal of Remote Sensing, 15(6): 1295-1305.

3. Ray S.S., Dadhwal V.K. and Navalgund R.R. (2002). "Performance evaluation of an irrigation command area using remote sensing: a case study of Mahi command area". Agriculture water management, Gujarath, India, 56(2): 81-91.

4. Santhi., Muttiah. and Arnold. (2004). "A GIS-Based regional planning tool for irrigation demand assessment and savings using SWAT". Soil and water division of ASAE, 48(1): 137-147.

5. Shahriar. and Mohammed Ahmadul Hoque. (2011). "Interactive Information System (IIS) for Irrigation Management". International Water Management Institute, Sri Lanka, pp:5-6.

6. National Wei-Taw Lin., Yi-Fong Ho. and Ming-Daw Su. (2000). "GIS for Irrigation Management in Irrigation Associations". Seminar Paper, FAO Irrigation and Drainage, D1:71-80.

7. Waldo Ojeda-Bustamantea., Juan Manuel González-Camachob., Ernesto Sifuentes-Ibarrac., Esteban Isidroa. and Luis Rendón-Pimenteld.(2007). "Using spatial information systems to improve water management in Mexico". Agricultural Water Management, 89(1-2): 81-88.

8. Vidhya R. Karmegam M. and Venugopal K. (2003). "GIS based diagnostic analysis of irrigation system performance assessment of Bhadra command area at disaggregated level". published in GIS development web site under Geospatial Application Papers.

9. Van Lieshout A.M. and J.A.M. Brouwer.(2009). "Irrigation water requirement". Earth Resources Surveys, International Institute for Aerospace Survey and Earth Sciences (ITC), P.O. Box 6, 7500 AA Enschede, The Netherlands, pp.119-124. 